\title{
Study on Practical Innovation Ability Cultivation of Management Postgraduates Based on QFD
}

\author{
Liangqing Feng ${ }^{1,2, ~ *, ~ D a l i ~ H u a n g ~}{ }^{1}$, Wenchuan $\mathrm{Li}^{1}$, Zhaodi Kong ${ }^{1}$, Kunkun Zeng ${ }^{1}$ \\ ${ }^{1}$ School of Economics and Management, Nanchang Hangkong University, Nanchang, China \\ ${ }^{2}$ College of Management and Economics, Tianjin University, Tianjin, China
}

Email address:

flq9848@163.com (Liangqing Feng)

*Corresponding author

\section{To cite this article:}

Liangqing Feng, Dali Huang, Wenchuan Li, Zhaodi Kong, Kunkun Zeng. Study on Practical Innovation Ability Cultivation of Management Postgraduates Based on QFD. Education Journal. Vol. 5, No. 5, 2016, pp. 113-120. doi: 10.11648/j.edu.20160505.15

Received: August 31, 2016; Accepted: September 13, 2016; Published: September 28, 2016

\begin{abstract}
Based on the exiting education problems of management postgraduates, focusing on improving the practical innovation ability of management postgraduates, this paper transforms the social requirements to the universities' education by the Quality Function Deployment (QFD) method. With the conversion of interrelation matrices, the most important influence factors are found. The research shows that: the practical activities management and tutor team construction are the two most important factors for postgraduates to cultivate practical innovation ability, which are helpful for the education organization to find the influence factors and take measures to enhance the important factors' construction.
\end{abstract}

Keywords: Management Postgraduates, Practical Innovation Ability, Quality Characteristics, Quality Requirements, Quality Function Deployment

\section{Introduction}

With the development of economic and society, it puts forward higher requirements to high-level management. That traditional teaching and cultivation model cannot fulfill the requirements of society anymore. More and more comprehensive abilities are needed except the professional skills. Especially the practical innovation ability requires schools to strengthen practical innovation ability of management postgraduates [1]. While, there still exist lots of problems about the cultivation of postgraduates. Many studies have put forward on them.

At present, the researches on cultivation problems about practical innovation ability of postgraduates mainly focus on two aspects as follows: one aspect focuses on the time since the enrollment expansion, they hold on idea that because the enrollment expansion, the universities have no enough energy to give more resource and attention to every postgraduate. Some scholars study on problems of postgraduate education, some point out main reasons and give some advice [2], and some compared the difference between Chinese and foreigner about cultivation mode $[3,4]$. The other focuses on cultivation of innovation ability [5, 6] and practice ability [7] about postgraduates. In summary, the above researches have played a positive role on improving the practical innovation ability of postgraduates.

QFD [8] is a powerful mechanism which helps to identify customer requirements and translate them into the appropriate technical requirements [9]. In the early 1970s, Japanese quality management master Yoji Akao and Shigeru Mizuno, come up with a theory of Quality Function Deployment (QFD), which is a way to systematically transform customer requirements into the product (service) or production service quality requirements. Recently, the researchers applied the QFD method to serve the problem of service quality and product quality [10-13]. Liang applied the QFD method to design the new product research and development [14] and Wu applied the QFD method to study the problem that how to cultivate leisure sports management talent [15].

Many researchers have also applied the quality management tool, QFD, to study graduated education $[16,17]$. However, there still are few studies aim to improve practical innovation ability of management postgraduates based on quantitative methods that how to improve the practical 
innovation ability, Though lots of scholars have studied this problem while most studies only just display the problem and then put forward some suggestions, which are lack of the reason that why those ideas are given. This paper analyzes the exiting education problems of management postgraduates by an effective method QFD, which makes it possible to study the qualitative problem by a quantitative solution.

This paper carries on the questionnaire in the management postgraduates and tutors of Nanchang. Using QFD to analyze the practical innovation ability of management postgraduates by three stages of House of Quality (HOQ), and systematically designs the ability cultivation process system; at last, this paper tries to come up with some suggestions to improve practical innovation ability of management postgraduates.

\section{Research Method}

\subsection{Questionnaire}

Taking higher education schools in Nanchang as the example, a questionnaire survey about requirements analysis on practical innovation ability of management postgraduates was conducted, the issuance of this questionnaire mainly adopts electronic questionnaires and written text questionnaires. Since April 20, 2014, 150 questionnaires were issued, including 115 management postgraduates and 35 tutors. As of May 15, 2014, 120 effective questionnaires were taken back; so the effective recovery rate is $80 \%$, which includes 83 boys and 37 girls.

Sample analysis: according to the importance of the ability scores rated by questionnaire investigation objects, through calculating the mean and variance of the tertiary demand indicators; then, with sorting and merging the information, and neatening it by the affinity diagram method, the practical and innovation ability requirements index of management postgraduates were obtained (as shown in table (1)).

\subsection{Quality Function Deployment}

Basic principle of QFD: based on HOQ (House of Quality, HOQ) [18] principle (as shown in fig. (1)), according to the customer's demand, QFD unfold the customer's demand. HOQ provides a basic tool which can convert customer requirements to product technical requirements, transform product technical requirements to critical parts characteristics, and transfer critical parts characteristics to critical process steps etc.

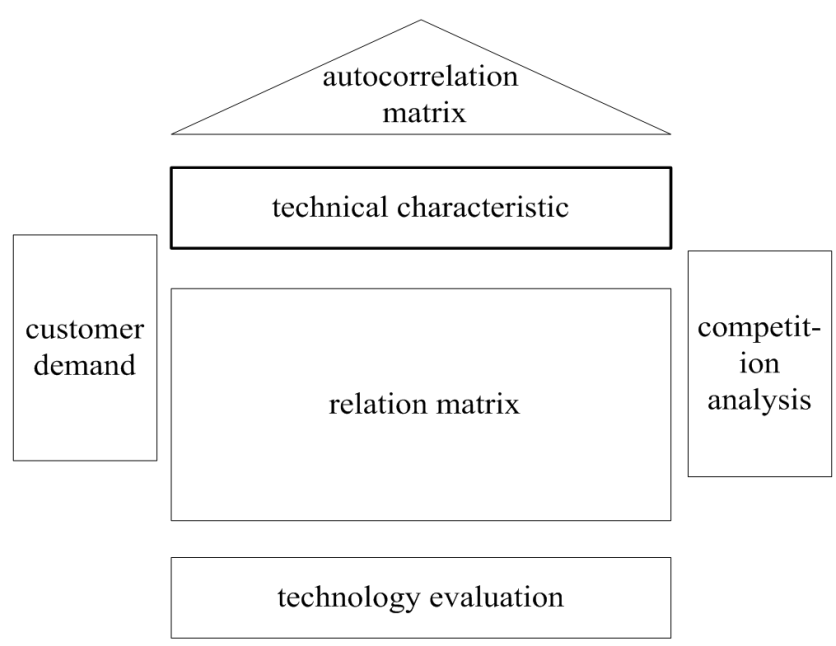

Fig. 1. HOQ structure.

QFD of Practical Innovation Ability of Management Postgraduates: based on HOQ and association analysis method, the target should be mapped to the quality control each stage of practical innovation ability of management postgraduates. Then it needs to make sure quality requirements of target needs oriented in every stage and build QFD model of practical innovation ability of management postgraduates (in Fig. 2).

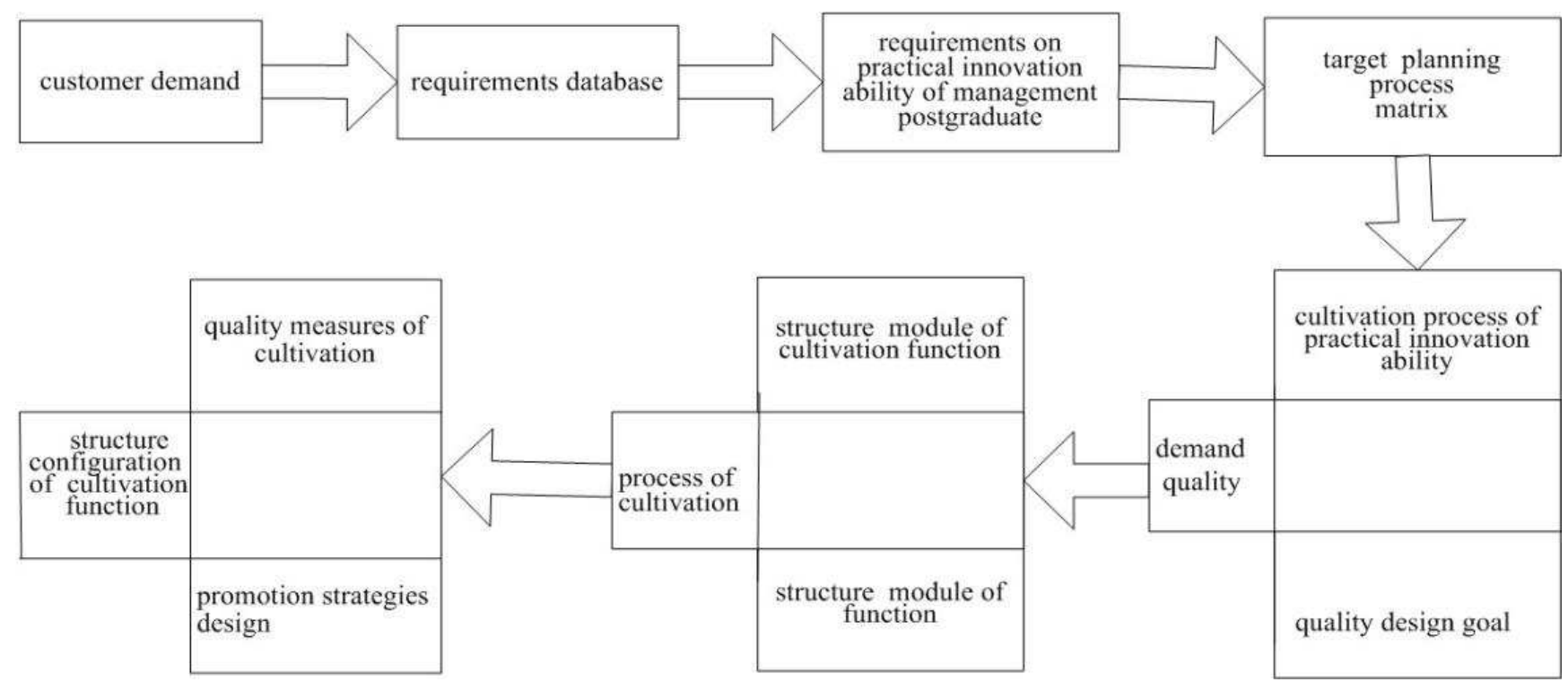

Fig. 2. Hierarchical QFD framework. 


\section{Results}

\subsection{Matrix of Target Panning Process}

In order to set up the matrix of target planning, it needs to combine social demand with the actual situation of similar schools, then do the competitive analysis about the data (in table (1)).

Table 1. First-stage HOQ.

\begin{tabular}{|c|c|c|c|c|c|c|}
\hline \multicolumn{3}{|c|}{ Quantitative expansion of quality requirements } & \multicolumn{4}{|c|}{ Competitive analysis matrix of cultivation } \\
\hline \multirow{2}{*}{ First } & \multirow{2}{*}{ Second } & \multirow{2}{*}{ Third } & \multicolumn{2}{|c|}{ Importance evaluation } & \multicolumn{2}{|c|}{ Competitive evaluation } \\
\hline & & & Society & Our school & Importance & Our school \\
\hline \multirow{16}{*}{$\begin{array}{l}\text { Practical } \\
\text { innovation } \\
\text { ability }\end{array}$} & \multirow{5}{*}{$\begin{array}{l}\text { Practical } \\
\text { innovation } \\
\text { literacy }\end{array}$} & Physical and psychological quality & 4 & 4 & 4 & 4 \\
\hline & & Team spirit & 4 & 3 & 4 & 3 \\
\hline & & Coordination & 3 & 4 & 4 & 4 \\
\hline & & Enquiring mind & 3 & 4 & 4 & 4 \\
\hline & & Innovation thinking & 5 & 4 & 5 & 4 \\
\hline & \multirow{5}{*}{$\begin{array}{l}\text { Innovation } \\
\text { knowledge } \\
\text { structure }\end{array}$} & Innovation theory knowledge & 3 & 4 & 4 & 3 \\
\hline & & Foundations of management science & 4 & 4 & 4 & 4 \\
\hline & & Discipline theory knowledge & 4 & 5 & 5 & 4 \\
\hline & & Professional knowledge & 5 & 4 & 5 & 3 \\
\hline & & cross-disciplinary knowledge & 5 & 4 & 5 & 4 \\
\hline & \multirow{6}{*}{$\begin{array}{l}\text { Practical } \\
\text { innovation } \\
\text { quality }\end{array}$} & Data processing capability & 3 & 3 & 3 & 3 \\
\hline & & Data analysis capability & 4 & 4 & 4 & 4 \\
\hline & & Innovation experiment capability & 4 & 5 & 5 & 4 \\
\hline & & Innovation design capability & 4 & 5 & 5 & 4 \\
\hline & & Innovation management capability & 3 & 4 & 4 & 3 \\
\hline & & Engineering application capability & 4 & 5 & 5 & 3 \\
\hline
\end{tabular}

Table 1. Continued.

\begin{tabular}{|c|c|c|c|c|c|c|c|c|}
\hline \multicolumn{3}{|c|}{ Quantitative expansion of quality requirements } & \multicolumn{6}{|c|}{ Competitive analysis matrix of cultivation } \\
\hline \multirow[b]{2}{*}{ First } & \multirow[b]{2}{*}{ Second } & \multirow[b]{2}{*}{ Third } & \multicolumn{2}{|c|}{ Quality planning } & & \multicolumn{3}{|c|}{ Target planning } \\
\hline & & & $\begin{array}{l}\text { Average } \\
\text { of similar } \\
\text { schools }\end{array}$ & $\begin{array}{l}\text { Target } \\
\text { quality } \\
\text { Evaluation }\end{array}$ & $\begin{array}{l}\text { levels } \\
\text { increase } \\
\text { rate }\end{array}$ & $\begin{array}{l}\text { Difference } \\
\text { evaluation }\end{array}$ & $\begin{array}{l}\text { Absolute } \\
\text { weight }\end{array}$ & $\begin{array}{l}\text { Relative } \\
\text { weight }\end{array}$ \\
\hline \multirow{16}{*}{$\begin{array}{l}\text { Practical } \\
\text { innovation } \\
\text { ability }\end{array}$} & \multirow{5}{*}{$\begin{array}{l}\text { Practical } \\
\text { innovation } \\
\text { literacy }\end{array}$} & Physical and psychological quality & 4 & 4 & 1 & & 4 & 3.82 \\
\hline & & Team spirit & 4 & 4 & 1.33 & $\mathrm{~B}$ & 6.92 & 6.61 \\
\hline & & Coordination & 4 & 4 & 1 & & 4 & 3.82 \\
\hline & & Enquiring mind & 4 & 4 & 1 & & 4 & 3.82 \\
\hline & & Innovation thinking & 4 & 5 & 1.25 & $\mathrm{C}$ & 7.5 & 7.17 \\
\hline & \multirow{5}{*}{$\begin{array}{l}\text { Innovation } \\
\text { knowledge } \\
\text { structure }\end{array}$} & Innovation theory knowledge & 3 & 4 & 1.33 & B & 6.92 & 6.61 \\
\hline & & Foundations of management science & 3 & 4 & 1 & & 4 & 3.82 \\
\hline & & Discipline theory knowledge & 4 & 5 & 1.25 & $\mathrm{C}$ & 7.5 & 7.17 \\
\hline & & Professional knowledge & 4 & 5 & 1.67 & A & 12.5 & 11.94 \\
\hline & & cross-disciplinary knowledge & 4 & 5 & 1.25 & $\mathrm{C}$ & 7.5 & 7.17 \\
\hline & \multirow{6}{*}{$\begin{array}{l}\text { Practical } \\
\text { innovation } \\
\text { quality }\end{array}$} & Data processing capability & 3 & 3 & 1 & & 3 & 2.87 \\
\hline & & Data analysis capability & 3 & 4 & 1 & & 4 & 3.82 \\
\hline & & Innovation experiment capability & 4 & 5 & 1.25 & $\mathrm{C}$ & 7.5 & 7.17 \\
\hline & & Innovation design capability & 3 & 5 & 1.25 & $\mathrm{C}$ & 7.5 & 7.17 \\
\hline & & Innovation management capability & 4 & 4 & 1.33 & & 5.32 & 5.08 \\
\hline & & Engineering application capability & 4 & 5 & 1.67 & A & 12.5 & 11.94 \\
\hline
\end{tabular}

Note: for the column of "differentiation evaluation" A means 1.5, B means 1.3, C means 1.2.

In this stage, the importance data of "our school" is obtained by the questionnaire; importance evaluation date of "our school" is obtained according to the investigation on demand indicators of statistical results by the rounding of average; target quality evaluation is based on our school importance and the similar competition level of colleges and universities. The data can be described as follows:

(1) Levels increase rate $=$ target quality evaluation/competitive evaluation of our school.

(2) Absolute weight $=$ levels increase rate $\times$ importance $\times$ difference evaluation.
(3) Relative weight $=$ absolute weight/total absolute weight.

\subsection{Matrix of Cultivation Design Process}

By converting quality requirements to quality characteristics of cultivation process that can be measured or executed, and through considering related quality characteristics evaluation results and cultivation process of other schools' management postgraduates, each part of cultivation design quality was analyzed, the quality characteristics of target were emerged (in table (2)). 
Table 2. Second-stage HOQ.

\begin{tabular}{|c|c|c|c|c|c|c|c|c|}
\hline \multicolumn{3}{|c|}{ Quality requirements } & \multicolumn{6}{|c|}{ Quality characteristics } \\
\hline First & Second & Third & $\begin{array}{l}\text { Theory } \\
\text { Study }\end{array}$ & $\begin{array}{l}\text { Practice } \\
\text { in school }\end{array}$ & $\begin{array}{l}\text { Practice out } \\
\text { of school }\end{array}$ & $\begin{array}{l}\text { Research } \\
\text { practice }\end{array}$ & Dissertation & $\begin{array}{l}\text { Quality } \\
\text { weight }\end{array}$ \\
\hline \multirow{16}{*}{$\begin{array}{l}\text { Practical } \\
\text { innovation } \\
\text { ability }\end{array}$} & \multirow{5}{*}{$\begin{array}{l}\text { Practical } \\
\text { innovation } \\
\text { literacy }\end{array}$} & Physical and psychological quality & $\circ$ & $\circ$ & ○ & ० & & 3.82 \\
\hline & & Team spirit & & $\circ$ & ○ & ० & & 6.61 \\
\hline & & Coordination & & ० & ○ & $\Delta$ & & 3.82 \\
\hline & & Studying spirit & $\circ$ & $\Delta$ & $\Delta$ & (0) & () & 3.82 \\
\hline & & Innovation thinking & () & $\circ$ & $\circ$ & () & (0) & 7.17 \\
\hline & \multirow{5}{*}{$\begin{array}{l}\text { Innovation } \\
\text { knowledge } \\
\text { structure }\end{array}$} & Innovation theory knowledge & (0) & $\Delta$ & $\Delta$ & (0) & (0) & 6.61 \\
\hline & & Foundations of management science & (0) & $\Delta$ & $\circ$ & $\circ$ & $\circ$ & 3.82 \\
\hline & & Discipline theory knowledge & (0) & ○ & $\circ$ & $\circ$ & $\circ$ & 7.17 \\
\hline & & Professional knowledge & $\circ$ & $\circ$ & $\circ$ & (0) & $\Delta$ & 11.94 \\
\hline & & Cross-disciplinary knowledge & (0) & $\circ$ & ० & (0) & $\circ$ & 7.17 \\
\hline & \multirow{6}{*}{$\begin{array}{l}\text { Practical } \\
\text { innovation } \\
\text { quality }\end{array}$} & Data processing capability & $\circ$ & $\circ$ & $\Delta$ & ० & ० & 2.87 \\
\hline & & Data analysis capability & $\circ$ & $\circ$ & $\circ$ & $\circ$ & (0) & 3.82 \\
\hline & & Innovation experiment capability & $\Delta$ & (0) & (0) & (0) & $\Delta$ & 7.17 \\
\hline & & Innovation design capability & $\Delta$ & (0) & $\circ$ & () & $\circ$ & 7.17 \\
\hline & & Innovation management capability & $\Delta$ & $\Delta$ & (0) & $\Delta$ & $\circ$ & 5.08 \\
\hline & & Engineering application capability & $\Delta$ & (0) & (0) & $\circ$ & $\circ$ & 11.94 \\
\hline \multicolumn{3}{|c|}{ Important degree of quality characteristics } & 179.72 & 206.95 & 210.89 & 242.15 & 173.81 & \\
\hline \multirow{2}{*}{\multicolumn{2}{|c|}{ Competitive evaluation }} & Our school & 3 & 4 & 3 & 3 & 4 & \\
\hline & & Average of similar schools & 3 & 4 & 4 & 4 & 4 & \\
\hline \multicolumn{3}{|c|}{ Target of quality design } & 4 & 5 & 5 & 5 & 4 & \\
\hline
\end{tabular}

Note: $\Delta=1$, means the weak correlation; $\mathrm{o}=2$, means correlation; $(0)=3$, means strong correlation.

In the above matrix, the correlation between quality requirements and quality characteristics is based on the expert discussion and judgment about relative degree. We can clearly find that the higher of relevance, it means the connection closer between quality requirements and quality characteristics.

\subsection{Matrix of Cultivation Function Process Configuration}

In order to obtain the correlation between quality characteristics and cultivation function module, it needs to take two subsystems: the cultivation management and cultivation resource. Then, it needs to build a correlation matrix, which could transform quality characteristics importance to module importance (as shown in table (3), table (4))

Table 3. Third-stage HOQ (1).

\begin{tabular}{|c|c|c|c|c|c|c|}
\hline \multirow{2}{*}{\multicolumn{2}{|c|}{ Quality characteristics }} & \multicolumn{4}{|c|}{ Subsystem of “cultivation management” } & \multirow{2}{*}{$\begin{array}{l}\text { Important degree } \\
\text { of quality } \\
\text { characteristics }\end{array}$} \\
\hline & & $\begin{array}{l}\text { Teaching } \\
\text { management } \\
\text { module } \\
\end{array}$ & $\begin{array}{l}\text { Tutors } \\
\text { management } \\
\text { module } \\
\end{array}$ & $\begin{array}{l}\text { Practical activities } \\
\text { management } \\
\text { module }\end{array}$ & $\begin{array}{l}\text { Dissertation } \\
\text { management } \\
\text { module } \\
\end{array}$ & \\
\hline \multicolumn{2}{|c|}{ Theory Study } & () & & & & 179.72 \\
\hline \multicolumn{2}{|c|}{ Practice in school } & & ○ & (a) & & 206.95 \\
\hline \multicolumn{2}{|c|}{ Practice out of school } & & & () & & 210.89 \\
\hline \multicolumn{2}{|c|}{ Research practice } & $\circ$ & ० & (2) & ० & 242.15 \\
\hline \multicolumn{2}{|l|}{ Dissertation } & ० & ○ & $\circ$ & (2) & 173.81 \\
\hline \multicolumn{2}{|c|}{ Module importance } & 1371.08 & 1245.82 & 2327.59 & 1005.73 & \\
\hline \multirow{2}{*}{$\begin{array}{l}\text { Competitive } \\
\text { evaluation }\end{array}$} & Our school & Good & Good & Good & Good & \\
\hline & Average of similar schools & Good & Good & Excellent & Good & \\
\hline \multicolumn{2}{|c|}{ Target of quality design } & Excellent & Excellent & Excellent & Excellent & \\
\hline
\end{tabular}


Table 4. Third-stage HOQ (2).

\begin{tabular}{|c|c|c|c|c|c|c|c|c|}
\hline \multirow{2}{*}{\multicolumn{2}{|c|}{$\begin{array}{l}\text { Quality } \\
\text { characteristics }\end{array}$}} & \multicolumn{6}{|c|}{ Subsystem of "cultivation resource" } & \multirow[b]{2}{*}{$\begin{array}{l}\text { Important degree } \\
\text { of quality } \\
\text { characteristics }\end{array}$} \\
\hline & & $\begin{array}{l}\text { Discipline } \\
\text { platform } \\
\text { module }\end{array}$ & $\begin{array}{l}\text { Tutors } \\
\text { module }\end{array}$ & $\begin{array}{l}\text { Laborator } \\
\text { y module } \\
\text { in school } \\
\end{array}$ & $\begin{array}{l}\begin{array}{l}\text { Practice base } \\
\text { out of school } \\
\text { module }\end{array} \\
\end{array}$ & $\begin{array}{l}\text { Teaching } \\
\text { platform } \\
\text { module }\end{array}$ & $\begin{array}{l}\text { Teachers } \\
\text { ' faculty } \\
\text { module }\end{array}$ & \\
\hline \multicolumn{2}{|c|}{ Theory study } & $\Delta$ & $\Delta$ & & & 0 & (0) & 179.72 \\
\hline \multicolumn{2}{|c|}{ Practice in school } & $\Delta$ & $\circ$ & () & & ० & & 206.95 \\
\hline \multicolumn{2}{|c|}{ Practice out of school } & & $\circ$ & & (0) & & & 210.89 \\
\hline \multicolumn{2}{|c|}{ Research practice } & ० & (0) & $\circ$ & $\Delta$ & & & 242.15 \\
\hline \multicolumn{2}{|l|}{ Dissertation } & ० & $\circ$ & & & $\circ$ & $\circ$ & 173.81 \\
\hline \multicolumn{2}{|c|}{ Module importance } & 1218.59 & 2089.47 & 1105.15 & 874.82 & 1120.96 & 886.78 & \\
\hline \multirow{3}{*}{\multicolumn{2}{|c|}{$\begin{array}{ll}\text { Competitive } & \text { Our school } \\
\text { evaluation } & \text { Average of similar schools } \\
\text { Target of quality design }\end{array}$}} & Good & Good & Good & Good & Good & Excellent & \\
\hline & & Excellent & Good & Excellent & Good & Good & Good & \\
\hline & & Excellent & Excellent & Excellent & Good & Excellent & Excellent & \\
\hline
\end{tabular}

\subsection{Matrix of Cultivation Quality Design Process}

In conclusion, the importance of each module can be obtained easily. To compare the priority levels of modules, therefore, according to the output of third-stage HOQ, combining with the functional management of schools, it will be wise to build a matrix as follows (as shown in table (5)).

Table 5. Fourth-stage HOQ.

\begin{tabular}{|c|c|c|c|c|}
\hline \multirow{2}{*}{$\begin{array}{l}\text { Project of management } \\
\text { control }\end{array}$} & \multirow{2}{*}{$\begin{array}{l}\text { Module } \\
\text { importance }\end{array}$} & \multicolumn{3}{|c|}{ Guarantee measures of cultivation quality } \\
\hline & & Quality goal & Scheme and measure & Implementer \\
\hline $\begin{array}{l}\text { Discipline platform } \\
\text { construction }\end{array}$ & 1218.59 & Excellent & $\begin{array}{l}\text { Discipline platform construction planning } \\
\text { Implementation plan of discipline platform construction } \\
\text { Quantitative evaluation standard system of discipline platform level } \\
\text { Construction planning of tutors }\end{array}$ & Postgraduate school \\
\hline Tutors construction & 2089.47 & Excellent & $\begin{array}{l}\text { Implementation plan of tutors construction } \\
\text { Quantitative evaluation standard system of tutors level }\end{array}$ & Postgraduate school \\
\hline $\begin{array}{l}\text { Teaching platform } \\
\text { construction }\end{array}$ & 1120.96 & Excellent & $\begin{array}{l}\text { Teaching platform construction planning } \\
\text { Implementation plan of teaching platform construction } \\
\text { Quantitative evaluation standard system of teaching platform } \\
\text { construction }\end{array}$ & Postgraduate school \\
\hline $\begin{array}{l}\text { Practice platform } \\
\text { construction }\end{array}$ & 1979.97 & Excellent & $\begin{array}{l}\text { Practice platform construction planning } \\
\text { Implementation plan of practice platform construction } \\
\text { Quantitative evaluation standard system of practice platform } \\
\text { construction }\end{array}$ & School of postgraduate \\
\hline $\begin{array}{l}\text { Teachers' faculty } \\
\text { module }\end{array}$ & 886.78 & Excellent & $\begin{array}{l}\text { Teachers' faculty construction planning } \\
\text { Implementation plan of teachers' faculty construction } \\
\text { Quantitative evaluation standard system of teachers' faculty } \\
\text { construction }\end{array}$ & Postgraduate school \\
\hline Teaching management & 1371.08 & Excellent & $\begin{array}{l}\text { Design and implementation of quantitative evaluation standard } \\
\text { system of Teachers' faculty Construction teaching level }\end{array}$ & $\begin{array}{l}\text { The office of } \\
\text { postgraduate cultivation }\end{array}$ \\
\hline Tutors management & 1245.82 & Excellent & $\begin{array}{l}\text { Design and implementation of quantitative evaluation standard } \\
\text { system of tutors level }\end{array}$ & School of postgraduate \\
\hline $\begin{array}{l}\text { Practical activities } \\
\text { management }\end{array}$ & 2327.59 & Excellent & $\begin{array}{l}\text { Design and implementation of quantitative evaluation standard } \\
\text { system of practical activities level }\end{array}$ & $\begin{array}{l}\text { The office of } \\
\text { postgraduate cultivation }\end{array}$ \\
\hline $\begin{array}{l}\text { Dissertation } \\
\text { management }\end{array}$ & 1005.73 & Excellent & $\begin{array}{l}\text { Design and implementation of quantitative evaluation standard } \\
\text { system of dissertation level }\end{array}$ & $\begin{array}{l}\text { The office of training } \\
\text { postgraduate }\end{array}$ \\
\hline
\end{tabular}

\section{Discussion and Analysis}

From the First-stage HOQ, the matrix on process of target planning, it can be obviously find that the innovation thinking ability, professional knowledge and cross-disciplinary knowledge and the engineering application ability, occupy an important position on the practical innovation requirement of management postgraduates.

The data in table (5) shows that: the practical activities management and the tutor team construction are the most important influence factors to improve the practical innovation ability cultivation of management postgraduates, while the teaching management and the dissertation management have little significant influence on it.

According to this analysis, the education organization can find the important influence factors, then further propose the reform methods of the tradition teaching and management, and cultivate the social requirements, which get a high weight in the whole requirements. 
By this way, it would be helpful for educational organization to take measures to improve the practical innovation ability of management postgraduates.

\section{Recommendations}

Taking Nanchang Hangkong University as an example, some promotion strategies for practical innovation ability of management postgraduates are put forward.

\subsection{Enhancing the Cultivation of Practical Ability}

It needs to build the system of "school-based catch-up-cooperation of schools-cooperation between schools and enterprises".

\subsubsection{Professional School Experiment Platform Construction}

Some obviously owning a nature of engineering majors, such as Industrial Engineering (IE), project management, whose scientific research and practice innovation need the experiment platform support. The university needs to increase proportion of practice and enhance investment in laboratory. Taking the IE as an example, building man-machine simulation system and aviation products production system will improve postgraduates' experiment simulation analysis ability and innovation ability; learning SPSS software will improve the ability of data analysis.

\subsubsection{Platform Construction of Schools' Cooperation}

For example, the schools who have the IE postgraduates or the management science and engineering, through building joint cultivation plan, can let the postgraduates draw lessons from experience and make up the shortfall; building joint innovation competition and cooperation cultivation projects can improve students' innovation experiment ability and design ability.

\subsubsection{Base Construction Cooperation between Schools and Enterprises}

By setting up the mechanism of school-enterprise cooperation, it will promote the cooperation and exchange between schools, scientific research units and enterprises, which are helpful for constructing mode of industry-university-research cooperation, also will improve the mechanism of postgraduates practice cultivation.

\subsection{Strengthening the Construction of Tutor Team}

In order to improve scientific research practice and extracurricular practice ability of management postgraduates, for the management science and engineering, project management and IE, it need to set up a "double tutor type" tutor team, which is a team based on mainly full time duty, owning high quality and high sense of responsibility.

\subsubsection{Creating Quantitative Evaluation Standard System of Tutors'Level Mechanism}

To enhance the tutor competition consciousness, we should introduce competition mechanism, establish and improve the teacher management and assessment mechanism, and increase the science research influence on teacher performance, which will arise the tutors' potential; abolishing tutor tenure, raising competition awareness and regularly doing investigation on the present situation of guidance supervision and evaluation, it is better to try to cultivation a group of high level tutors owning academic innovation ability and high quality in their mind.

\subsubsection{Building Tutor Team Structure to Keep the Tutors' Academic Thoughts Actively}

The teaching and guidance must keep pace with the times, so schools should increase the tutor construction investment; expand the scope of tutors' election, appropriately introduce foreign experts to improve academic thinking activity degree. For example, the IE major, introduced from abroad, seems should be paid more attention about increasing communication opportunities with foreign teachers and expanding tutors' teaching thinking.

\subsubsection{Setting up a "Double Tutor Type" Tutor Team, to Rich Tutors' Practice Background}

Schools need to hire senior engineer from enterprises and institutions as the tutor out of school, and regularly invite them to take case lecture and practice guidance. For example, Nanchang Hangkong University hires industrial engineer, quality engineer from Jiangxi aviation enterprise etc, as tutors out of school. At the same time, encouraging tutors in school to do interview to enterprises, which will help them to link the science research with enterprise practice.

\subsection{Strengthening Discipline Platform Construction}

Schools should open interlaced subjects, build "diversity" discipline platform based on strong disciplines.

\subsubsection{Building Discipline Public Platform Should Reflect "Interlace"}

According to the cross of knowledge elements, it should reasonably set up discipline public platform construction. For example, Nanchang Hangkong University can rely on the aviation advantage, combine characteristics of professional, according to the basic, comprehensive, open and innovative principle, construct "interlaced" discipline public platform.

\subsubsection{Building Professional Discipline Platform Should Reflect "Progressive"}

According to the difficulty degree of knowledge and practice, schools should follow "steps" to construct professional discipline platform. For instance, firstly, they need to set up the professional knowledge study, then cultivate their practice ability, follow the rules that from theory to practice, from in school to out of school, finally implement gradually discipline platform planning.

\subsubsection{Building Quantitative Evaluation Standard System of Discipline Level Should Reflect "Scientific"}

School of management should take "scientific" as the basic standard, establish quantitative evaluation criteria system, 
optimize management system, and encourage teachers and students to conduct scientific research and scientific exploration.

\subsection{Improving Course Teaching Management}

It needs to combine the classroom teaching and extracurricular teaching to realize the "dual-track" type teaching mode.

\subsubsection{Perfecting Course Examination and Assessment System}

To perfect course teaching evaluation system, colleges need to choose evaluation methods, evaluation index and evaluation standard. For instance, setting up special course teaching supervision, which is helpful to evaluate and improve teachers' teaching methods in timely.

\subsubsection{Innovating Classroom Theory Teaching Method}

Combining the teachers' scientific research project and curriculum, promoting research-oriented teaching to arise the teachers' and students' interest about study, which will cultivate students' innovation thinking ability; through the enterprise case teaching, combining theory with practice, the students' innovation theory learning ability and studying spirit will be strengthened.

\subsubsection{Enriching Extracurricular Practice Teaching Content}

To improve management postgraduates' innovation thinking ability, schools need to hold activities such as academic seminar and academic forum based on the cooperation of schools. To improve students' data processing ability and engineering application ability, it is better for schools.

\subsection{Improving the Management of Dissertation}

Schools should perfect management system, create quantitative evaluation standard system of dissertation level mechanism, be strict to degree granting, and try to cultivation excellent postgraduates.

\subsubsection{Strengthening Dissertation Quality Management}

It has difference between management postgraduates and engineering postgraduates, the management postgraduates' mostly finish dissertations by the way of questionnaire to collect data and software to simulation. So in the process of dissertation management, schools should strengthen reliability evaluation about the data and the quality evaluation in each stage, should establish a fair and equitable quality evaluation criteria system of dissertation management, and strengthen supervision and management to ensure the quality of dissertation.

\subsubsection{Improving the Quality Management about Degrees-Awarded}

Colleges and universities should implement double controlling, school and college controlling together, to realize secondary management mechanism between college and school, and to enhance the theory study and practice management.

\subsubsection{Establishing a Strict Censorship System of Degree-Awarded}

Colleges and universities should perfect system construction of degree-awarded, establish a scientific audit system and strict audit process to improve the quality of degree-awarded. Of course, they also need to adopt comprehensive evaluation strategy to the scientific research ability, professionalism, practical and innovation ability of postgraduates.

\section{Conclusions}

This paper studies the practical innovation ability cultivation of management postgraduates based on QFD. The research shows that the practical activities management and tutor team construction are the two most important factors for postgraduates to cultivate practical innovation ability. Recommendations proposed in this paper are helpful for the education organization to find the influence factors and take measures to enhance the important factors' construction.

\section{Acknowledgments}

This paper is supported by the Education and Teaching Reform Research Project of Degree and Postgraduate of Jiangxi Province (Grant No. JXYJG-2013-093), the Teaching Reform for higher education schools Research in Jiangxi Province (Grant No. JXJG-14-8-7) and Jiangxi Science Fund for Distinguished Young Scholars.

\section{References}

[1] A. P. Hu and H. Yan. The further thinking and exploration to improve the quality of postgraduates education. China's higher education research. Vol. 7, 2001, pp. 79-80.

[2] S. H. Wang and H. Dai. Problems since graduates education expansion and countermeasures. Journal of Changchun Education College. Vol. 23, No. 3, 2007, pp. 34-39.

[3] Z. H. Wang. Disorderly graduate education and its correction. Journal of graduate education. Vol. 1, 2012. pp. 14-21.

[4] A. J. Duan and X. Q. Guo. Training pattern evolution and enlightenment between Chinese and foreign postgraduates. University Education. Vol. 22, NO. 1, 2013, pp. 1-4.

[5] D. Luo. Explore on the training ways of postgraduates' practical ability. Journal of the south of china today. Vol. 9, 2008, pp. 73-74

[6] S. H. Wang and G. Q. Zhang. Research on the training system of students' ability of innovative practice: A case study on the discipline of control science and engineering. Journal of Shangdong University. Vol 28, No. 3, 2001, pp. 274-276.

[7] H. G. Chen and G. Q. Liang. Quality control model for graduate training based on QFD. China higher education research. Vol. 2, 2007, pp. 18-22.

[8] K. Masao and A. Yoji. Quality Function Development and CWQC in Japan. Quality Progress. Vol. 16, No. 10, 1983, pp. $25-28$. 
[9] G. Z. Jia and M. Bai. An approach for manufacturing strategy development based on fuzzy-QFD. Journal of Computers \& Industrial Engineering. Vol. 60, No. 3 2011, pp. 445-450.

[10] Y. Z Zeng, B. W. Wang and X. L. Liu. The application of fuzzy QFD in improving the quality of port services, Vol. 1, 2015, pp. 103-106.

[11] Y. Diao. The study of university library service quality guarantee system based on QFD, Vol. 1, 2015, pp. 78-81.

[12] Y. Zhan. And J. Zhou. The research of manufacturing product quality index evaluation model based on QFD. Vol. 2. 2016, pp. $55-61$.

[13] H. C. Ren and Y. F. Chu. The product requirement analysis based on improving HOQ. Vol. 34, NO. 9, 2016, PP. 235-23
[14] P. L. Liang and M. Y. Zhou. The study of priority design based on QFD, Vol 23, 2015, pp. 110-111.

[15] M. H. Wu and G. Shen. The thinking of cultivating leisure sports management talent based on QFD, Vol. 34, 2015, pp. 178-179.

[16] L. L. Song and C. Y. Dou. The QFD application in course quality evaluation of colleges and universities. China Management Information, Vol 12, No. 2, 2009, pp. 109-122.

[17] B. Liu and H. B. Lin. Training innovation ability of graduates based on the discipline construction of platform. Journal of research in teaching. Vol. 34, No. 2, 2011, pp. 33-36.

[18] J. R. Hauser and C. Don. The House of Quality, Harvard Business Review. Vol. 66, No. 3, 1988, PP. 63-73. 